\title{
INSIDE THE MIND AND HEART OF HOMO AEDIFICATOR
}

\section{TOWARDS REVEALING THE PSYCHOLOGICAL MEANING OF HISTORIC BUILDINGS AND SITES ${ }^{\#}$}

\author{
BARBARA FOGARASI* ${ }^{*}$ - ANDREA DÚLL ${ }^{* *}$ \\ "PhD student. ELTE Eötvös Loránd University, Faculty of Education and Psychology, \\ Doctoral School of Psychology, Institute of People-Environment Transaction, \\ Kazinczy u. 23-27. 424. H-1075 Budapest, Hungary. E-mail: fogarasi.barbara@ppk.elte.hu \\ ${ }^{* *}$ DSc, professor. ELTE Eötvös Loránd University, Faculty of Education and Psychology, \\ Institute of People-Environment Transaction, Kazinczy u. 23-27. 423. H-1075 Budapest, Hungary. \\ Budapest University of Technology and Economics, Department of Sociology and Communication. \\ E-mail: dull.andrea@ppk.elte.hu
}

While the reasons that lead to the current crisis of the heritage preservation sector in Hungary are manifold, it is worth looking into what might be done to draw attention to some issues that may help consolidate the ground of common values; the foundation, upon which a meaningful dialogue can be constructed, leading to the appreciation of and willingness to care for the historic environment by all actors. There seems to be a hidden conflict between the values of conservation experts and those of laypeople. Possessing thorough knowledge about the nature of historical and architectural values and trained to easily identify these, we are bound to focus more on people, their meanings and values. Much can be learned from pervious, human-centred architectural theory and practice, some of which are reviewed in the study, with special attention to the work of Gyula Hajnóczi. Referring to his space theory and ideas about the perception of space, we are especially grateful for his term homo aedificator suggesting that architecture satisfies material and spiritual needs universal to all human beings. Recognizing the challenges that stem from the differences between architects and non-architects, and likewise, heritage professionals and laypeople, the concepts of environmental psychology can help us show the way to universal values. We look into the method of the semantic differential scale to identify the affective meanings of built historic environments. The first steps of an empirical psychological research allow us to see into the minds and hearts of heritage professionals by assessing how they qualify the subject of their daily expertise. While these preliminary results are definitely intriguing, shedding light on how professionals tend to give meaning, our research continues with the aim to reveal the attitudes and meanings people associate with built historic heritage and find viable tools to mitigate the discrepancies between the profession and the general public.

Keywords: environmental psychology, built heritage, historic environment, spatial perception, psychological meaning, semantic differential scale

\# The paper was written in the framework of ELTE Eötvös Loránd University Thematic Excellence Programme 2020, supported by National Research, Development and Innovation Office (TKP2020-IKA-05). The research was supported by "Doctoral Projects Joint Research Assistance 2019/20" by ELTE Eötvös Loránd University Faculty of Education and Psychology, awarded to Iván Zsolt Berze, Barbara Fogarasi, Gyöngyvér Gyene and Andrea Dúll as advisor (B10401/20). This publication was supported by the National Cultural Fund of Hungary (NKA) under Grant Number 101108/547.

$\triangle$ Corresponding author. 
"When man builds a house or constructs a building, he invents space, exterior and interior alike. He does not stand alone in nature with his ability to build, as many species of the animal kingdom create their own hideouts to store food, reproduce etc. What distinguishes the activity of the builder

man from the instinctive construction of animals is that he not only builds a shelter for himself following his instincts, but also raises a home for his gods with faith and conscience. Taking advantage of the double meaning of the Latin word-aedes-denoting both a dwelling and a church, it simply yet adequately illustrates that architecture can satisfy man's needs not only materially but spiritually. Man is: homo aedificator."'

\section{INTRODUCTION}

While the profession of heritage protection is suffering a serious crisis in Hungary, there is also a realignment of priorities in a more subtle way internationally, focusing more on people, their meanings and values. ${ }^{2}$ Jeremy C. Wells, one of the few scholars worldwide researching the topic of evolving heritage conservation practice with the goal of making historic preservation more human-centred, acknowledges some of the initiatives and critiques of the past decades in this regard, but maintains that "our understanding of built heritage is still severely lacking from a psychological perspective." Attempting to start to fill this gap, we begin by taking a broad, historical and interdisciplinary look at the human notion of space and its perception. It is worthwhile to turn to the writings of Gyula Hajnóczi, who "enchanted by architecture $[\ldots]$ was a polyhistor and specialist, teacher, theorist and a practicing heritage preservationist." ${ }^{\prime 4}$ His rich oeuvre overarches several themes: the architectural history of antiquity, practical conservation of historic buildings and a "universal architecture theory." 5 From the point of view of psychology - both modern experimental cognitive psychology ${ }^{6}$ and environmental psychology ${ }^{7}-$ it is exciting to read his architectural theory book Vallum and Intervallum, ${ }^{8}$ in which, aside from constructing an analytical theory, the architect-author attempts experimentally to "justify that space is structured, taking as a starting point the relationship between building structure and space, as well as man and space. In other words, [this book] wants to delineate the structure of architectural space." ${ }^{10}$ Based on his experiments ${ }^{11}$ involving common themes from psychology, and on the foundation of his extensive knowledge, Hajnóczi articulates a legitimate criticism of $20^{\text {th }}$ century mainstream behav-

\footnotetext{
${ }^{1}$ Hajnóczi 1992a. 2.

${ }^{2}$ Wells 2020; Mayes 2018.

${ }^{3}$ Wells 2020. 8.

${ }^{4}$ Szabó 1996-1997. 199-200.

${ }^{5}$ Kubinszky 2001. 4.

${ }^{6} \mathrm{Cf}$. Sternberg-Sternberg 2015.

${ }^{7}$ Cf. Steg-van den Berg-de Groot 2013.

${ }^{8}$ Hajnóczi 1992.

${ }^{9}$ cf. Hajnóczi 1985.

${ }^{10}$ Hajnóczi 1992b. 7.

${ }^{11}$ E.g. Hajnóczi 1993.
} 
ioural and cognitive psychology as applied to architecture: "A fundamental problem already at the outset of the research was psychologists' views on the issues of physical determinism, that is, its rejection. The majority of psychologists consider the concept of spatial effect and spatial experience to be extremely uncertain and swampy, saying that partial effects may indeed be 'made up' and justified, but this will not explain the true reality of space in its entirety. Spatial experience varies from person to person, so to speak, according to differences in gender, age, education, mood, social status etc., thus the semiotic and sociological approach to the philosophy of the problematics of space promises much firmer results than the psychological one, which was not able to give a satisfactory response to the question either."'12 These thoughts might have been the self-accusation of "in gang psychologists" Hajnóczi's popular term used among architects when referring to insider psychologists. Born in the mid- $20^{\text {th }}$ century, environmental psychology did just that: relying on the turn in ideas about space in social sciences, ${ }^{13}$ it emphasized that not only behaviour but all psychological processes should be interpreted exclusively in their environmental/spatial contexts. This standpoint of environmental psychology gives the basis for examining and revealing what is in our minds, that is, what kind of psychological meaning people associate with historic architectural spaces.

\section{THE PERCEPTION OF SPACE AND THE IMPACT OF ARCHITECTURAL SPACE ON PEOPLE}

In the discourse of architectural theory and practice, when it comes to assessing good design, a basic reference point is often the objective Vitruvian Triad of firmness, commodity and delight. Hajnóczi himself confirms this by stating "almost involuntarily: [...] [these] principles of architecture [...] have continual value despite the ever changing functional demands and the highly developed building technology that has been produced since antiquity." 14 Such characteristics are intrinsic to the building and though the assessment may touch upon the general user experience, there is often little consideration of the personal values, meanings and attitudes associated with the piece of architecture. Indeed, when understanding how one judges a building or a space, an elementary distinction should be made between perceiving architecture and the architecture itself. ${ }^{15}$ Without elaborating on the cognitive process models of perception, it is crucial to recognize that the information received at the end of the perceptual process is structured into mental representations as the brain tries to make sense of all the visual images. Regarding the environment, as the brain processes

\footnotetext{
${ }^{12}$ Hajnóczi (n. d.). We owe thanks to János Krähling for providing the manuscript.

${ }^{13}$ Soja 1989.

${ }^{14}$ Kubinszky 2001. 6.

${ }^{15}$ Julean 2016. 6.
} 
information, it forms mental maps ${ }^{16}$ and can thereby navigate through space. ${ }^{17}$ The importance of the individual's active movement in environmental perception is highlighted by ecological psychologists. ${ }^{18}$ Traditional, primarily cognitive, theories of perception imply that only sensations are direct experiences and they mediate all other kinds of experience. Rejecting this, the Gestalt psychologists ${ }^{19}$ recognized that the meaning or the value of a thing seems to be perceived just as immediately as its colour, ${ }^{20}$ yet they could not quite explain why. Advocating a person-environment compatibility, ecological psychology, and more specifically James J. Gibson's optical-psychological spatial perception theory, ${ }^{21}$ consider the process of perception on the same terms as Hajnóczi, who states that the sensing of space should be viewed as a "multisensory process," 22 in which "the relationship between man and space is so complicated that not all aspects have been clarified to this day. Man's entire psychophysiological being is involved in the perception of space. Sense of space is defined not merely by data transmitted through the senses, but also its processing through mental, memory, emotional etc. mechanisms. ${ }^{.23}$

With regards to processing environmental stimuli, Hajnóczi draws attention to the role of the architect in recognizing that "responses given to physical stimuli are not innate, but rather vary with culture, age, gender and individual differences. For this reason, buildings should not be designed for average reaction schemes or even consider the 'average person' as a basis. The psychological effects of physical stimuli can be 'planned' in advance. Man does not utilize space randomly. A building is a complex organism; therefore, the architect must be aware of the psychology of organization, as well as the fundamentals of psychology, so that he would be able to conduct valid and useful experimental tests. This is the only way to arrive at determining the basic dimensions: liking, orderliness, comfort and the satisfaction of individual requirements. ${ }^{24}$ With his theory of affordances, Gibson claims that components of the environment hold values in themselves and this information is immediately there. For instance, "if a surface of support with the four properties (horizontal, flat, extended, and rigid) is also knee-high above the ground, it affords sitting on. We call it a seat in general, and [...] it should look sit-on-able." ${ }^{25}$ Thus, Gibson maintains that the values of things are perceived immediately and directly, because the affordances of things for an observer are specified in stimulus information. ${ }^{26}$ The ecolog-

\footnotetext{
${ }^{16}$ Lynch 1960. 89.

${ }^{17}$ Stea 1974. Cited in Julean 2016. 5.

${ }^{18}$ Dúll 2009. 105.

${ }^{19}$ Cf. Wagemans et al. 2012.

${ }^{20}$ Gibson 1979. 129.

${ }^{21}$ Gibson 1979.

${ }^{22}$ Hajnóczi (n. d.).

${ }^{23}$ Hajnóczi 1992b. 51.

${ }^{24}$ Hajnóczi 1992b. 14-15.

25 Ibid. 120.

${ }^{26}$ Ibid. 131.
} 
ical approach suggests that it is less important to consider what is inside your head (representations) than "what your head is inside of." 27

It is intriguing to look at how theoreticians approached the idea of space, that thing that surrounds us, breaking it down to palpable geometric elements. Although perception is not merely visual, architectural theoretical thinking has followed the development of the senses leading to the hegemony of the vision. This is reflected in Alois Riegl's writings, who underscored the history of architecture as an evolutionary progression from haptic modes of perception to optical modes.$^{28} \mathrm{He}$ defines the concept of space as an intangible void, the air in between spatial boundaries of surfaces with changing depth. ${ }^{29}$ Riegl's theory emphasizes the concept that the viewer sees via a bodily experience and synthesizes an understanding of his own being through this perception. ${ }^{30}$ This is reflected in the above described ecological perception approach, though Riegl also comments on the impact of the environment on its user, maintaining that "works of art engender a mood in the viewer." 31

Several other $20^{\text {th }}$ century architects and theoreticians were attracted to the idea of analysing space and researching space perception to understand the human experience and how architectural design affects its users. Luigi Moretti was interested in the moment when one observes and starts to perceive and comprehend the space around them. He prepared models of building interiors, translating sequences of architectural space. By modelling the immateriality of space, he developed a tool to identify and analyse the spatial characteristics, the order and the reference system, which essentially became an affective relationship formed between the subject and the space surrounding them. ${ }^{32}$ Hajnóczi had similar ambitions to visually represent space by attributing a space-initiating effect to spatial boundaries. His analytical theory of architectural space consisted of breaking down the elements of the surfaces forming space into elementary units, defining each unit's space-initializing capacity, and then using these to construct prominent buildings of each major period of architecture history. ${ }^{33}$ As he describes in his book, Hajnóczi assigned force fields to plane surfaces based on human vision, forming geometric shapes and depicting these graphically to demonstrate space intensity or space quality. Recognizing that space intensities have an effect on a person's sense of space, the novelty in Hajnóczi's space theory lies in providing a tool to create a harmonious human environment. Other philosophers and theorists also speculate about experiencing the built environment. Walter Benjamin thinks of architecture "as a medium that is directed toward the distracted urban crowd, since it is a form of art that is perceived best in an absentminded state. [...] We notice architecture in the city casually, i.e., not by paying

\footnotetext{
${ }^{27}$ Mace 1977.

${ }^{28}$ Schwarzer 1991. 55.

${ }^{29}$ Riegl 1989. Cited in Mezős 1999.

${ }^{30}$ Morgenthaler 2018. 331.

${ }^{31}$ Riegl, 1929. Quoted by Morgenthaler 2018. 331.

${ }^{32}$ Lucarelli 2018.

${ }^{33}$ Mezős 1999.
} 
particular attention to them. [...] Distracted reception has become the preferred method of perception in the age of mechanical reproduction." ${ }^{34}$ Regardless of whether perceived directly and consciously or in such a distracted way as suggested by Benjamin, environmental psychology maintains that the built environment does impact us; furthermore, we also have an effect on our environment.

\section{ENVIRONMENTAL PSYCHOLOGY}

On our quest to find out how the historic environment impacts us we need to look further into environmental psychology, which claims that human behaviour is never independent of the physical context in which it occurs. An individual's personality, their perception of others and their social context and the physical environment all have equal parts in forming one's behaviour. Thus, environmental psychology always investigates socio-physical contexts. ${ }^{35}$ Furthermore, it assumes a transactional interaction between people and physical space, in which there is a bidirectional relationship between environment and behaviour. ${ }^{36}$ Such interactions form a personenvironment fit $^{37}$ on three levels: cognitive (knowledge, representation), behavioural (use of space) and affective (preferences, conscious and not conscious attitudes, appraisals). It is therefore important to recognize that aside from the artistic, architectural and historical values intrinsic to the fabric of built heritage and easily identified by historic building experts, people associate values linked to experiencing the place. These values, however, are not evident and cannot be directly deduced from the heritage site, rather they unfold through exploring the person-environment transactions. $^{38}$

Upon investigating the attitudes to the built historic environment it is crucial to familiarize ourselves with two psychological constructs: place attachment and place identity. Environmental psychology and design theory studies have long recognized that people relate emotionally to places and objects. ${ }^{39}$ Research has shown that the perception of space and spatial orientation are essentially never independent of the experienced or not conscious affective processes and conversely, mental-spatial representations and cognitive maps are personal, reflecting individual knowledge and experience about the given place..$^{40}$ In other words, a person does not only have feelings towards other people but towards the physical environment and objects. These emotive responses may be momentary feelings or lasting preferences and at-

\footnotetext{
${ }^{34}$ Benjamin 1936. Cited in Morgenthaler 2018. 329.

${ }^{35}$ Dúll 2009. 29.

${ }^{36}$ Stokols 1978. 256.

${ }^{37}$ Proshansky-Ittelson-Rivlin 1970. 176.

${ }^{38}$ Dúll 2017. 344.

${ }^{39}$ Dúll 2017. 120.

${ }^{40}$ Ibid.
} 
titudes. ${ }^{41}$ Research found that in those places where one spends longer periods of time during which they experience something of significance, place attachment ${ }^{42}$ will form. At the same time, research revealed that places are not equally important to all people. The mechanism of place attachment is similar to that of human attachment: if a person, be it a child or an adult, is attached to a place (in the case of human attachment to a person, for instance, the mother) then they will seem happy when they are there (with the mother) and show sadness or distress when they leave the place (like when they are not near the attachment person.) ${ }^{43}$ Place attachment forms the basis of a psychological well-being stemming from the ability to access the subject of attachment, a given place, that is, if the person is allowed to be in the place he loves. Place attachment is a - mostly - positive affective bond between a person and a place: a strong tendency/intention/desire to be in or near a place. Place attachment is thus crucial in self-defining processes: we consider important places to be parts of our self, strengthening the sense of self-stability and continuity, that is, identity manifesting itself in place identity. ${ }^{44}$ Since space is abstract, it is seen, known, and felt in discrete ways..$^{45} \mathrm{~A}$ special feature of historic environments is that place attachment is both personal and collective ${ }^{46}$ buildings are part of collective memory.

In conventional social psychology's theories of self, ${ }^{47}$ the self is defined as fundamentally social. The sense of self originates from an early learning process in which we learn to differentiate ourselves from others. Similarly, the places we feel attached to are not only important because they fulfil physical needs, but also due to their own intrinsic values (calm, safe, etc.) According to Harold M. Proshansky, familiar and secure places induce a sense of competence and autonomy in us; this is why we feel that these places belong to us and characterize us since, in essence, they are part of our identity. ${ }^{48}$ Francis T. McAndrew suggests that the experience of self-identity and place identity often merge; for instance, the self indelibly contains the psychological imprint of important places, like our first home, grandma's garden, the kindergarten, the playground, school, our favourite pub, etc. In a psychological sense we identify with these privileged places, ${ }^{49}$ which may become integrated into our identity. The extent of this integration depends on how well the given place serves to realizing one's desired goals and activities. ${ }^{50}$ Thus, our identity is inseparable from our knowledge about the physical environment. Human personal experiences are all placed in the dimensions of time and space, which are themselves indivisible. There is no such

\footnotetext{
${ }^{41}$ Ibid. 121.

${ }^{42}$ Stokols-Shumaker 1981. 457; Hummon 1992. 257.

${ }^{43}$ Chawla 1992. 63.

${ }^{44}$ Dúll 2017. 126.

${ }^{45}$ Wells 2020. 3.

${ }^{46}$ Relph 1976. 28.

${ }^{47}$ E.g. Mead 1934/1973.

${ }^{48}$ Proshansky 1978. 155.

${ }^{49}$ McAndrew 1993.

${ }^{50}$ Stokols-Shumaker 1981. 459.
} 
autobiography that tells a story describing "what" happened and "when" it happened without mentioning the space where these events took place. Speaking of "where" automatically brings about "with whom" we did "what." Perceiving space in this way is indispensable for organizing our memories and structuring our life. ${ }^{51}$

\section{ARCHITECT-NON-ARCHITECT HERITAGE PROFESSIONAL-LAYPERSON}

According to research in environmental psychology, the environment-multisensory process $^{52}$ of professionals (architects, historic building experts) differs significantly from that of laypersons. Several studies found a number of differences between the mental spatial representation of architects and non-architects. ${ }^{53}$ Some of these studies compared aesthetic preferences and found that the two groups assess and conceptualize buildings differently. ${ }^{54}$ In their experiment comparing the environmental perception of architects and laypersons by asking them to assess high-rise office buildings, Robert Gifford and his colleagues found that the difference can already be identified at the level of perception; that is, what and how architects see differs from what and how laypersons see. ${ }^{55}$ In his comparison, Kimberly Devlin found that non-architects were inclined to evaluate buildings based on a preference- and familiarity-based like-dislike dichotomy, while architects tended to interpret architecture in terms of more abstract conceptual issues ${ }^{56}$ in more distinct, loaded and complex categories ${ }^{57}$ Furthermore, architects' assessments follow a unified pattern and their standards and discernments are identical, while non-architect laypersons produce more heterogeneous ratings about the architectural environment. ${ }^{58}$ Architects' expertise, attitudes, tools and knowledge are organized in an extremely complex system during their university formation and practice, which are fundamentally and distinctively different from the laypersons' spatial representations based on naïve environmental competences. It is believed that architects are taught what to prefer and their formal training tends to focus their aesthetic standards; laypersons, on the other hand, are more influenced by their background (age, gender, education level) and actual mood. ${ }^{59}$ Another issue discovered by research is that not only do architects have different preferences, but they often do not understand what the public likes. ${ }^{60}$

\footnotetext{
${ }^{51}$ Downs-Stea 1973/2004. 12.

${ }^{52}$ Cf. Csanády 2019.

${ }^{53}$ E.g. Chase-Chi 1981.

${ }^{54}$ Gifford et al. 2000. 167.

55 Ibid.

${ }^{56}$ Devlin 1990. 241.

${ }^{57}$ Dúll 2017; Somogyi 2019.

${ }^{58}$ Gifford et al. 2000. 181.

59 Ibid.

${ }^{60}$ Ibid. 167.
} 
At the same time, on a behavioural level, architects as space users have similar reactions to laypersons. ${ }^{61}$ For example, research revealed ${ }^{62}$ that in a workplace situation the same factors (noise, lighting, lack of control over the office environment) cause stress and dissatisfaction for architects the same way, despite having better spatial competences, than for non-architects. Another interesting finding from a research studying the perception of urban environment by adults, adolescents and architects ${ }^{63}$ is that the three groups differ significantly in their perceptual schemes. Adolescent city dwellers base their perceptions on immediate sensation of stimuli, such as colour, light, and busyness. The significance of physical aspects decreases with age and more abstract categories of interpretation and meaning become relatively important, without applying complex spatial qualities. This study found that architects' perceptual schemes are characterized by the relative importance of spatial qualities, like measure and scale, spatial coherence, visual diversity, spatial definiteness and relation to environment. The difference between spatial experts and "spatial laypersons" ${ }^{\prime 64}$ can already be seen at the beginning of their professional training. By the end of their studies, not only will their spatial mind-sets and environmental attitudes have changed significantly, but architects possess a series of visualization and spatial analytic tools and methods to express and communicate their experiences, evaluations, and viewpoints, which are not known to and not understood by laypersons. ${ }^{65}$ At the same time, environmental psychology research ${ }^{66}$ tells us that the environmental representations of everyday people, though varied, are not less complex than those of architects. As Françoise Navez-Bouchanine postulates: the designer has logic, the inhabitant has competence.

An almost direct parallel can be made with regards to the relationship and lack of common ground between heritage professionals and non-professionals. As suggested by Wells, "laypeople do not seem to value historic places for their inherent historicity; rather, laypeople appreciate historic places for reasons that are antithetical to accepted practice" and have to do with their own personal history. ${ }^{67} \mathrm{He}$ further claims that the "evidence for the inherent conflict between the values of conventional preservation/conservation experts and the values and meanings of laypeople is substantial and incontrovertible"68 and refers to Laurajane Smith's (2006) concept of the "authorized heritage discourse," namely that heritage preservation practice is based on the professional values of historians, archaeologists, and architects; essentially, those who created the rules and regulations under which they practice. The authorized heritage discourse is marked by an official language and communication style

\footnotetext{
${ }^{61}$ Dúll 2017. 214.

${ }^{62}$ Salama-Courtney 2013. 52-64.

${ }^{63}$ Pennartz-Elsinga 1990. 709-711.

${ }^{64}$ The term in Hungarian "térlaikus" is used by Dúll 2017. 181; Dúll et al. 2018. 88.

${ }^{65}$ Dúll et al. 2018. 88.

${ }^{66}$ Dúll 2017. 218.

${ }^{67}$ Wells 2020. 7.

${ }^{68}$ Ibid.
} 
that must be used when discussing the value of historic buildings and places. This implies that "many of the values and meanings that laypeople hold for the historic environment are simply ignored and discarded because they are incongruent with statutory practice." ${ }^{69}$ We may add that in Hungary the values and meanings of laypeople are not only ignored but are generally not even known. We have argued earlier that there is a burning need to part from the expert-driven paradigm and embrace integrated valuation, in which social, environmental and even economic aspects are considered. ${ }^{70}$

The profession-layperson tension is released with the concept of Hajnóczi's homo aedificator and it is at this point that his complex oeuvre meets the mind-set of environmental psychology. Historic buildings and sites are the subject of multi-sensation by both experts and laypersons, who each understand these sites in very different ways. "The built environment is not simply a physical environment, but an objectified form of behaviour, which - even in its debatable manifestations - is the sum of life processes realized with the particular tools of architecture," 71 perceived and processed by both professionals and laypersons. From this point of view, expert and non-expert are both receivers, who intend to comprehend - and do so on their own terms - the "meaning of form," 72 and use the architectural space based on this interpretation. Therefore, it is highly justified to inquire what people think about the built environment, especially historic places they live their everyday life in or sites they visit. What do these mean to them? How do they convey different meanings to the everyday user, the occasional guest and the expert who rigorously studies these spaces and intimately knows the hidden historical layers? Is it possible to comprehend our relationship with architectural heritage and how we respond to a decaying structure, a restored building or a reconstructed space? Do the concepts of originality and authenticity matter at all or does perceived credibility ${ }^{73}$ suffice? This train of thought may go as far as analysing how the built historic environment around us affects our behaviour, decisions, and momentary- and long-term psychological well-being. Very few studies deal with the psychological impact of built historic environments on individuals, communities and society, taking into account the aforementioned environmental psychological constructs of place attachment and place identity. The following section will consider how we may start looking into the attitudes and affective meanings associated with the built witnesses of the past, how these meanings may be measured and how they differ among heritage professionals and laypeople.

\footnotetext{
${ }^{69}$ King 2009. Cited in Wells 2020. 7.

${ }^{70}$ Fogarasi et al. 2015. 184.

${ }^{71}$ Hajnóczi 1992b. 15.

${ }^{72}$ Hajnóczi 1960. Quoted by Simon 1997.

${ }^{73}$ Cságoly 2017. 28.
} 


\section{MEANINGS OF THE BUILT HISTORIC ENVIRONMENT - THE SEMANTIC DIFFERENTIAL SCALE}

It is argued that the meaning attributed to the environment is both personal and collective. Echoing Hajnóczi's ideas, Philip Hubbard speculates that the sources of meaning of architecture, rather than being intrinsic to a set of physical characteristics, are in the person and his own interpretative mechanisms. This individual nature of perception suggests that "when looking at space, although we all 'see' the same thing, we operate and understand things differently mainly because of our different social, cultural, religious, and geographical backgrounds." ${ }^{74}$ At the same time, Hubbard refers to the idea that meaning is transmitted socially through "structures of perception, cognition and action common to all members of a group based on their education and culture." In this sense the meaning of the built environment is not as idiosyncratic as it might seem at first. ${ }^{75}$ Elaborating this idea with reference to David Lowenthal's work, the past exists both as an individual and collective construct insofar as some memories and stories are selective and personal, while there are many shared experiences and common values across members of similar socio-cultural groups. ${ }^{76}$ The meaning of a place includes its physical characteristics and related affective components (emotions, experiences. ${ }^{77}$ Since the person-environment relationship is multifaceted and tinted by emotion, the psychological meaning of a place cannot easily be described spontaneously in words. Moreover, even if we manage to express such a meaning, its interpretation by the listener may vary. Nevertheless, if we hear certain words, like opposing adjective pairs, e.g. nice-ugly, pleasant-unpleasant, we can immediately decide if they are appropriate for a given environment. This gives the basis for the psychological methods to measure meaning. ${ }^{78}$

Dealing with the concept of meaning we must analyse the roots of words through the philosophy of language and linguistics. When it comes to defining the meaning of "meaning" semantics differentiates between two principal methods, denotation and connotation. Denotation refers to the precise, explicit, literal definition of a word, whereas connotation represents associations, implicit suggestions, emotional and cultural implications..$^{79}$ In the 1950 's, the American psychologist Charles Osgood found that the meaning of various phenomena could be explained in terms of a "semantic space" defined by a relatively small number of dimensions, the three most important of which are evaluation (good/bad), strength (strong/weak) and activity (active, passive). ${ }^{80}$ These three dimensions refer to basic human phenomena and are

\footnotetext{
${ }^{74}$ Downs-Stea 1973. 21. Julean 2016. 1.

${ }^{75}$ Hubbard 1993. 365.

${ }^{76}$ Ibid. 366, referring to Lowenthal 1979.

${ }^{77}$ Dúll 2009. 109.

${ }^{78}$ Ibid. 114.

${ }^{79}$ Rosengren 2000. 59.

${ }^{80}$ Osgood-Suci-Tannenbaum 1957. 25.
} 
related to the most profound aspects of the meaning of human life. ${ }^{81}$ Osgood and his colleagues intended to reveal the semantic space of human thinking through analysing the responses given to a special kind of attitude test he devised, the since widely used "Osgood scale" or "Semantic Differential." Thus, semantic differential scales are used to measure connotative or emotional meanings through eliciting people's appraisals and attitudes towards a wide variety of subjects. Respondents are given a concept, an object or a phenomenon and are then offered a set of antonym adjective pairs, such as ugly - beautiful, easy - difficult, placed on a 7-point bipolar scale. The respondent is then asked to rate the given concept by selecting a position on the scale, considering the subject to be more like one adjective of the pair or the other.

In the area of our interest, environmental settings, semantic differential scales have been applied on very few occasions, for instance, to compare architects' and non-architects' attitudes ${ }^{82}$ or for the evaluation of buildings ${ }^{83}$ urban and suburban settings,${ }^{84}$ and heritage sites ${ }^{85}$ Most of these scales are based on the adjectives used by Osgood or have been completed by adding further adjectives selected somewhat arbitrarily. A few scales related to the physical environment have been systematically constructed from scratch, like the one created to identify possible differences in the perception of chairs, revealing aspects of the man-environment interface. ${ }^{86}$ Indeed, it has been postulated that in order to achieve accurate measurements with the scale, its components should represent the words used in assessing the subject. ${ }^{87}$ Having qualifiers that describe concept-domain relevant traits was inevitable for Joyce Vielhauer Kasmar, whose research identified a "workable and meaningful lexicon" relevant to describe architectural spaces, as well as an environment description scale made up of 66 adjective pairs. ${ }^{88}$ She was motivated to do so because she maintained that though it may be tempting to borrow and use Osgood's semantic differential as the descriptive tool, "the terms comprising it may or may not have relevance for the description of environments and the terms may or may not have meaning for the user trying to describe architectural spaces. The results from a study which uses the semantic differential could be open to question if not to meaningless, misleading, or erroneous interpretation." ${ }^{89}$ Harold Alexander and his colleagues follow the same line of thought as they state, "to guarantee the validity of the resultant semantic components, it is therefore important that the stimuli used should represent the total stimuli genus, the modifiers should represent the common judgment criteria actually used, and the subjects should represent the potential consumers in a society." ${ }^{90}$

\footnotetext{
${ }^{81}$ Rosengren 2000. 60.

${ }^{82}$ Canter 1969; Alp 1993.

${ }^{83}$ Oostendorp 1978; Gifford 1980.

${ }^{84}$ Garling 1976; Horayangkura 1978.

${ }^{85}$ Ernawati-Moore 2014.

${ }^{86}$ Alexander et al. 1978.

${ }^{87}$ Pléh-Czigler 1979. 482.

${ }^{88}$ Kasmar 1970. 163.

${ }^{89}$ Kasmar 1970. 154.

${ }^{90}$ Alexander et al. 1978.
} 
In the Hungarian context, the first to develop a semantic differential scale used in environmental psychology (Environmental Semantic Differential Scale) to describe the quality of environment-behaviour interaction and study the connotative meaning of environments were Andrea Dúll and Róbert Urbán. ${ }^{91}$ Acknowledging that emotions both influence and play an important role in people-environment transaction, they strived to construct a reliable and valid semantic differential scale that targets relevant environmental traits and thereby measures the environment's emotional potential more precisely. ${ }^{92}$ Their work followed the methodological steps suggested by Pléh-Czigler (1979). They collected qualifiers describing the environment from people in actual physical spaces (university classrooms) stressing the ecological validity of the study. Going through the methodological process, the developed scale consisting of 36 adjective pairs was tested, again, in classrooms. The resulting Environmental Semantic Differential Scale ${ }^{93}$ is the first tool of its kind applied in further field research to elicit people's connotative meanings about the environment. ${ }^{94}$ The semantic differential is considered to be a useful psychometric scale to measure the non-conscious processes that lead to our attitudes and influence our actions concerning historic environments. Following from what has been said about its methodology above, in order to measure people's affective meanings most accurately, a scale developed specifically for built historic environments is needed.

\section{CONSTRUCTING A SEMANTIC DIFFERENTIAL SCALE FOR BUILT HISTORIC ENVIRONMENTS}

Since there is no known semantic differential measurement tool for the built historic environment, one of the objectives of our research ${ }^{95}$ is to construct one based on Osgood's methodology adapted by the Hungarian environmental psychologists. In order to acquire adjectives that faithfully describe historic buildings, a basic decision was made to elicit words from heritage professionals, who have the most in-depth knowledge about the subject. Another goal of the research supports this decision, namely that we intend to compare the attitudes and meaning associations formed by heritage professionals to those of laypeople. We hypothesize that the use of professional vocabulary will result in a more particular comparison. Those working in the heritage protection field, such as researchers, art historians, architecture historians, archaeologist, conservators, architects, landscape architects, and historic building inspectors have a very different take on historic buildings and sites, which are the

\footnotetext{
${ }^{91}$ The scale is called Környezeti Szemantikus Differenciálskála [Environmental Semantic Differential Scale] KSZD, Dúll-Urbán 1997.

${ }^{92}$ Dúll-Urbán 1997. 163.

${ }^{93}$ Ibid. 179.

${ }^{94}$ Dúll 2017.

${ }^{95}$ Cf. Fogarasi-Dúll, in print
} 
focus of their everyday work, than those who do not deal so intensively with historic environments, even if they experience them every day.

The research process aiming to construct a Semantic Differential Scale for Built Historic Environments was affected by the COVID-19 pandemic appearing in Europe in the spring of 2020. We were unable to collect data in situations requiring physical presence in historic spaces, but were able to use digital $2 \mathrm{D}$ and $360^{\circ}$ panoramic view photographs in virtual spaces. There is definitely a methodological difference in assessing a building or space depicted on a picture or a screen versus actually being physically there, even though several earlier studies about physical environments that used pictorial stimuli either do not reflect on this fact ${ }^{96}$ or even speak of the evidence of previous success with colour slides and photographs accurately reflecting responses on site. ${ }^{97}$ Jack L. Nasar compared pictorial stimuli and physical presence in his research and revealed significant correlations between the responses on site and the responses to the photographs, with no significant differences between the groups. ${ }^{98}$ Ahmet Vefik Alp's work used 1:20 scale models of different configurations of architectural space as stimuli for his semantic differential measures, with the belief that they will bring reliable results..$^{99}$ Other studies, at the same time, argue for the perceptual difference between space seen on pictures and real spatial experiences. ${ }^{100}$ Viewing an image calls for simpler mental and emotional processes than those occurring when fully immersed in a space with a complete bodily experience. It is not only because of our ability to move about in space that we experience differently, for instance, the relationship of spatial elements to each other, but alongside processing visual information a series of other conscious and non-conscious perceptions take place in the form of ambient effects. Furthermore, social interactions occur as an essential component of the socio-physical context. All of these are partly or completely missing when viewing a picture. For heritage professionals, who possess indepth background knowledge, previous experience and more complex spatial vision, the images of the historic buildings and sites probably evoke more than they do in the case of laypersons - reinforcing the validity of our research.

\section{INSIDE THE MINDS (AND HEARTS) OF HERITAGE PROFESSIONALS}

The process of constructing the semantic differential scale involved several rounds of inquiry from heritage professionals, allowing us to get a glimpse into the minds of specialists to see what they think about historic buildings and sites. Firstly, we elicited images to define the concept of historic buildings and sites, then we collected qualifiers that describe them. Analysing the responses lets us gain a picture of how

\footnotetext{
${ }^{96}$ Vielhauer 1965; Kasmar 1970; Gärling 1976; Horayangkura 1978; Gifford 1980.

${ }^{97}$ Nasar 1988, referring to Hershberger-Cass 1974; Shafer-Richards 1974; Zube-Pitt-Anderson 1974.

${ }_{98}$ Nasar 1988. 277.

${ }^{99}$ Alp 1993. 153.

${ }^{100}$ Gibson 1978; Dúll-Urbán 1997; Sedgwick 2003. 63; Somogyi 2015.
} 
the concept of built heritage is constructed in the heads of those who are most familiar with the subject.

As a first step, a survey was sent to 75 heritage professionals asking them to visually define the concept of historic buildings and sites by providing a maximum of 20 examples. 21 respondents gave 368 responses altogether. The examples generally specified a picture or a detailed description of what the image would depict. These were grouped in typological categories and sorted by frequency of occurrence, allowing for the selection of the 25 most representative typical historic buildings or sites by a group of 3 heritage experts. ${ }^{101}$ Due to the underrepresentation of foreign examples and to simplify the mental process of qualifying these in the next step, a decision was made to remain culturally homogeneous and use Hungarian sites only. The 25 images were used in a new survey sent to the same circle of heritage professionals, requesting them to write adjectives or qualifiers for each historic building or site.

Twenty-two respondents sent 1205 responses altogether, though not all answers were one word adjectives. The responses were sorted by frequency of occurrence and also by the number of respondents who used that word. For instance, the word "unique" occurred 14 times but was used by only 5 respondents (one respondent might have used it for several buildings or sites.) The responses were coded by a group of three researchers, consisting of a psychologist, a heritage specialist and a 'layperson', whose profession is from neither of these fields. ${ }^{102}$ Semantically similar words were identified and grouped together through a consensual process. All responses were considered, resulting in 72 groups of similar meaning, each comprising various number of responses. Each group received a flagship word that best described the group's overall meaning and was used frequently by respondents. Fifty-five responses were left out either because they were not qualifiers (e.g., church, exhibition, evening) or referred to an architectural style or period (e.g., medieval, industrial). The groups were then sorted into 7 categories, based on what the meanings imply. The

Table 1. The categories, examples, number of groups, number of qualifiers in groups and frequency of occurrence of responses provided by heritage professionals qualifying historic buildings and sites

\begin{tabular}{|c|l|l|c|c|c|}
\hline CATEGORY & EXAMPLES & $\begin{array}{c}\text { \# OF } \\
\text { GROUPS IN } \\
\text { CATEGORY }\end{array}$ & $\begin{array}{c}\text { \# OF } \\
\text { QUALIFIERS } \\
\text { IN GROUPS }\end{array}$ & $\begin{array}{c}\text { FREQUENCY } \\
\text { OF } \\
\text { OCCURENCE }\end{array}$ \\
\hline 1 & value judgement & dissonant, authentic, kitschy & 18 & 240 & 328 \\
\hline 2 & affective quality & intimate, unfriendly, spiritual & 15 & 112 & 195 \\
\hline 3 & visible feature & decorated, picturesque, uniform & 12 & 80 & 144 \\
\hline 4 & physical condition & ruiny, restored, layered & 8 & 94 & 134 \\
\hline 5 & neutral descriptive & ancient, urban, natural & 12 & 72 & 106 \\
\hline 6 & cognitive quality & $\begin{array}{l}\text { memorable, thought-provoking, } \\
\text { surprising }\end{array}$ & 5 & 33 & 46 \\
\hline 7 & related to function & used, functioning & 2 & 14 & 20 \\
\hline
\end{tabular}

\footnotetext{
101 The members of the expert group were László Hernyák, Miklós Okrutay and the first author.

102 The members of the coding group were the first author and fellow PhD students of the Doctoral School of Psychology - Eötvös Loránd University: Noémi Ádám and Gyöngyvér Gyene.
} 
categories, the number of groups in each category, the sum of the number of qualifiers making up the groups, and the frequency of occurrence of qualifiers (moderated by respondents) are summarized in Table 1 .

The findings show that far the most qualifiers signify some sort of value judgement. The group having the most diverse qualifiers under this category is "fake (Disney, oh no, it's a lie, lost authenticity, etc.)" 103 - a dreaded quality of historic sites by professionals. The weightiest groups in this category mostly imply positive evaluations, like "special (unique, rare, etc.)" followed by "monumental (grandiose, imposing, powerful, etc.)"; "splendid (sumptuous, luxurious, admirable, etc.)"; "valuable (significant, treasure, appreciated, etc.)" and "dignified (respectable, proud, royal, etc.)" Several responses at the same time take a critical approach, the most recurrent being "kitschy (ridiculous, weird, etc.)"; "to be restored (can be saved, last minute, etc.)"; "inaccessible (hidden, closed, etc.)"; "artificial (plastic, model-like, etc.)"; "excessive (overbuilt, exaggerated, etc.)" It is a basic human approach to immediately evaluate anything we come across on the basic terms of good-bad - as demonstrated in one of Osgood's main dimensions of meaning. ${ }^{104}$ In the case of a professional, however, it is probably even more common to feel authorized to assess the subject of his expertise, having both an inner drive and an outer expectation to do so. Whether a researcher, an architect, an inspector or a consultant, it is usually part of their daily task to make value judgements. This state of mind - especially if paired with tactless communication - is easily misinterpreted as intending to be elitist, superior and directive, distancing the heritage professional (and often the entire profession) from laypeople. ${ }^{105}$ The second most prevalent category comprises words related to an affective quality, the most frequent of which are "romantic (sentimental, imaginative, ideal, etc.)"; "likeable (sweet, dear, favourite, etc.)"; and "intimate (cosy, friendly, warm, etc.)" This finding is especially reassuring as it suggests that emotional attitudes towards historic buildings and sites do exist and even those who deal with built heritage on a daily basis are not devoid of such affective meanings. Feelings are essentially what makes us human and connects us as human beings. While exploring affective meanings of historic places in both professionals and lay actors is subject to further studies, it already shows the way to a common denominator, a firm ground upon which the relationship with other, non-professional people may be improved. Albeit the next three categories, visible feature, physical condition and neutral descriptive altogether consist of roughly as many qualifiers as value judgement alone, they highlight an important aspect. They demonstrate that the expert is inclined to look and see objectively, to acknowledge a building's physical features and conditions as a baseline for assessment. The most weighted groups in the categories of visible feature, physical condition and neutral descriptive are "nice (beautiful, pretty, breath-taking, etc.)"; "tidy (orderly, maintained, exemplary, etc.)"; "ancient (historic, old, worn, etc.)", respectively. It would be interesting to further analyse the order of responses by type, to see

\footnotetext{
${ }^{103}$ In the specific examples provided the group's flagship word is followed by some examples from the group in brackets.

${ }^{104}$ Osgood-Suci-Tannenbaum 1954. 36.

${ }^{105}$ Fogarasi 2017. 8.
} 
what the first reaction of professionals is - whether descriptive qualifiers are given prior to value judgements, the other way around or without any specific pattern. The fact that there are so few responses related to cognitive quality, including words related to memory and thought, is intriguing. It shows that professionals do not primarily think of built heritage as something interesting (nor boring), perhaps because it is a given that historic buildings and sites are in their interest and part of their daily routine. Some words that appeared in this category go beyond the level of simply being interesting to a deeper reflection on the subject, including "thought-provoking, philosophical, encouraging dialogue" and "meaningful, mysterious, inviting." The assumption regarding the little appearance of memory-related qualifiers is that heritage buildings for professionals, again as part of their job, are viewed less personally than for those who might connect their own life story to them. The results in the category related to function are also informative and may shed new light on the professional-layperson tension. The extremely small number of qualifiers within the two groups of "utilized" and "lively" appearing in this category suggests that heritage professionals generally do not think of historic sites in terms of use and functionality. Some qualifiers that make up the category are even derogative, like "too much money" and "business," implying the fear that the economic aspects that come with using a heritage building in contemporary life will necessarily destroy historic significance.

\section{CONCLUSION}

With the purpose of identifying the affective meanings associated with the built historic environment, the current study looked broadly into architectural theory and psychological considerations about the perception of space with special consideration of Gyula Hajnóczi's extensive writings. Highlighting the difference that exists between the perception of professionals and laypersons both in terms of architectnon-architect and heritage professional-layperson, we gave an outlook on environmental psychology and introduced a psychological assessment tool, the semantic differential scale, to begin to obtain some empirical evidence on the topic. The qualifiers collected from those who are most familiar with historic buildings and sites is a first step towards revealing the psychological meaning of the historic environment. By better understanding how heritage professionals perceive historic buildings, we can note the differences in their thinking and attitudes compared to laypersons, and thus bring them closer to construct a common ground for dialogue and decision making. Our research continues the development of the Semantic Differential Scale for Built Historic Environments with the help of which we plan to further explore affective psychological qualities in order to gain evidence of the psychological constructs of place attachment and place identity, which we suspect are present in people's attitudes towards historic built environments. Further research can analyse all people, including architects, heritage professionals and laypersons, because "everyone is a homo aedificator, including homo architectus."

${ }^{106}$ Hajnóczi 1992a. 5. 


\section{REFERENCES}

Alexander, Harold H. - Alexander, Marjorie A. - Tzeng, Oliver C. S.: Designing Semantic Differential Scales for a Universe of the Near Environment - Chairs. Home Economics Research Journal 6 (1978) 4. 293-304.

Alp, Ahmet Vefik: An Experimental Study of Aesthetic Response to Geometric Configurations of Architectural Space. Leonardo 26 (1993) 2. 149-157.

Canter, David: An Intergroup Comparison of Connotative Dimensions in Architecture. Environment and Behaviour 1 (1969) 1. 37-48.

Chase, William G. - Chi, M. T. H.: Cognitive Skill - Implications for Spatial Skill in Large-Scale Environments. In: Cognition, Social Behavior, and the Environment. Ed.: Harvey, John H. Lawrence Erlbaum, Hillsdale 1981. 111-136.

Chawla, Louise: Childhood Place Attachment. In: Place Attachment. Eds.: I. Altman, \& S. M. Low. Plenum Press, New York 1992. 63-87.

Cságoly, Ferenc: Mủemlékvédelem - kérdések és felvetések. [Heritage Preservation - Questions and Suggestions] Épités - Építészettudomány 45 (2017) 1-2. 19-30.

Csanády, Pál: Architectural Space Density: The Effect of Enclosure. Symmetry: Culture and Science 30 (2019) 1. 43-58.

Devlin, Kimberly: An Examination of Architectural Interpretation: Architects versus non-Architects. Journal of Architectural and Planning Research 7 (1990) 3. 235-244.

Downs, Roger M. - Stea, David: Cognitive Maps and Spatial Behavior - Process and Products. In: Image and Environment. Cognitive Mapping and Spatial Behavior. Eds.: Downs, Roger M. - Stea, David. Aldine Publ. Co., Chicago 1973. 8-26.

Dúll, Andrea: A környezetpszichológia alapkérdései - Helyek, tárgyak, viselkedés. [Fundamental Questions of Environmental Psychology - Places, Objects, Behaviour] L'Harmattan, Budapest 2009.

Dúll, Andrea: Épített környezet és pszichológia - a lokalitásélmény környezetpszichológiai vizsgálatai. [Built Environment and Psychology - Environmental Psychological Studies of Locality Experience] Akadémiai doktori értekezés. MTA, Budapest 2017.

Dúll, Andrea et al.: A szociofizikai önállóság első színtere: Építészhallgatók és térlaikus egyetemi hallgatók mentális térképábrázolásainak összehasonlítása. [The First Scene of Sociophysical Independence: Comparison of Mental Map Representations of Architecture Students and Spatial Layperson University Students] Magyar Pszichológiai Szemle 73 (2018) 1. 83-110.

Dúll, Andrea - Urbán, Róbert: Az épített környezet konnotatív jelentésének vizsgálata: módszertani megfontolások. [Examining the Connotative Meaning of the Built Environment: Methodological Considerations] Pszichológia 17 (1997) 2. 151-179.

Ernawati, Jenny - Moore, Gary T.: Tourists' and Residents' Impressions of a Heritage Tourism Site: The Case of Kampong Taman Sari, Indonesia. International Journal of Architectural Research 8 (2014) 3. 181-194.

Fogarasi, Barbara: Müemlékvédelmi paradigmaváltás. Örökségkalauz - örökségvédelmen alapuló közösségfejlesztéshez. [Paradigm Shift in Monument Protection. Heritage Guide - for Heritage-Lead Community Development] Forster Központ, Budapest 2017. 8. https://oroksegkalauz.seed.hu/ files/publications/320.pdf (accessed: 10 January 2021)

Fogarasi, Barbara et al.: The Nivegy-Valley Parish House Pilot Project - A Community-Embedded Cultural Heritage Rehabilitation. In: Heritage Counts. Eds.: Van Balen, K. - Vandesande, A. Garant Publishers, Antwerp 2015. 183-195.

Fogarasi, Barbara - Dúll, Andrea: Hogyan viszonyulunk a mủemlékekhez? - müemlékvédelem és környezetpszichológia. [What Attitudes do We Have for Historic Buildings and Sites? - Heritage Preservation and Environmental Psychology] In: Fiatal Müemlékvédök Fóruma. Conference proceedings. In print.

Gärling, Tommy: A Multidimensional Scaling and Semantic Differential Technique Study of the Perception of Environmental Settings. Scandinavian Journal of Psychology 17 (1976) 323-332. 
Gibson, James J.: The Ecological Approach to The Visual Perception of Pictures. Leonardo 11 (1978) $227-235$.

Gibson, James J.: The Ecological Approach to Visual Perception. Houghton Mifflin, Boston 1979.

Gifford, Robert: Environmental Dispositions and the Evaluation of Architectural Interiors. Journal of Research in Personality 14 (1980) 3. 386-399.

Gifford, Robert et al.: Decoding Modern Architecture - A Lens Model Approach for Understanding the Aesthetic Differences of Architects and Laypersons. Environment and Behavior 32 (2000) 2. $163-187$.

Hajnóczi, J. Gyula: Elemi térviszonylatok, térhatáselemek c. kisérletsorozat kiértékelése. Kézirat. [Elemental Spatial Relations, Spatial Effect Elements. Evaluation of a Series of Experiments. Manuscript] (no date)

Hajnóczi, J. Gyula: Láthatatlan építészet - térharmónia. [Inivisible Architecture - Spatial Harmony.] Épités- Épitészettudomány 17 (1985) 1-2. 73-80.

Hajnóczi, J. Gyula: Az építészeti tér genezise: I. rész. [The Genesis of Architectural Space: Part I.] Iskolakultúra 2 (1992a) 22. 2-10. https://ojs.bibl.u-szeged.hu/index.php/iskolakultura/article/ view/28788 (accessed: 29 January 2021)

Hajnóczi, J. Gyula: Vallum és intervallum - Az épitészeti tér analitikus elmélete. [Vallum and Intervallum - The Analytic Theory of Architectural Space] Akadémiai Kiadó, Budapest 1992b.

Hajnóczi, J. Gyula: Az építészeti tér genezise III.: az építészeti tér megteremtése. [The Genesis of Architectural Space III.: The Creation of Architectural Space] Iskolakultúra 3 (1993) 1. 20-33. https://ojs.bibl.u-szeged.hu/index.php/iskolakultura/article/view/28846 (accessed: 29 January 2021)

Horayangkura, Vimolsiddhi: Semantic Dimensional Structures - A Methodological Approach. Environment and Behavior 10 (1978) 4. 555-584.

Hubbard, Philip: The Value of Conservation: A Critical Review of Behavioural Research. The Town Planning Review 64 (1993) 4. 359-373.

Hummon, David M.: Community Attachment. Local Sentiment and Sense of Place. In: Place Attachment. Eds.: Altman, Irwin - Low, Setha M. Plenum Press, New York 1992. 253-278.

Julean, Dana: Why Architects See Things Differently. An Architectural Approach on Teaching Space Perception. European Scientific Journal 12 (2016) 1-8.

Kasmar, Joyce Vielhauer: The Development of a Usable Lexicon of Environmental Descriptors. Environment and Behavior 2 (1970) 2. 153-169.

Kubinszky, Mihály: Hajnóczi Gyula (1920-1996). In: Emlékbeszédek az MTA elhunyt tagjai felett 1999-2000. [Commemorative Speeches over the Deceased Members of the Hungarian Academy of Sciences 1999-2000] Ed.: Glatz Ferenc. Magyar Tudományos Akadémia, Budapest 2001. 3-6.

Lucarelli, Fosco: Luigi Moretti's Structures and Sequences of Spaces (1952). http://socks-studio. com/2018/12/09/luigi-morettis-structures-and-sequences-of-spaces/ (accessed: 20 January 2021)

Lynch, Kevin: The Image of the City. MIT Press, Cambridge 1960.

Mace, William M.: James J. Gibson's Strategy for Perceiving: Ask not What's Inside Your Head, but What Your Head Is Inside of. In: Perceiving, Acting, and Knowing. Toward an Ecological Psychology. Eds.: Show, R. - Bransford, J. Lawrence Erlbaum, Hillsdale 1977. 43-66.

Mayes, Thompson M.: Why Old Places Matter - How Historic Places Affect Our Identity and WellBeing. Rowman \& Littlefield, Lanham 2018.

McAndrew, Francis T.: Environmental Psychology. Brooks/Cole Publishing Company, Belmont 1993.

Mead, George H.: A pszichikum, az én és a társadalom. [Mind, Self and Society] Gondolat, Budapest 1934/1973.

Mezős, Tamás: Az építészeti tér fogalmának kialakulása - Hajnóczi Gyula emlékének. [The Development of the Concept of Architectural Space - In Memory of Gyula Hajnóczi] Kortárs Épitészet 1 (1999) 3. http://arch.et.bme.hu/arch_old/kortars3.html\#1 (accessed: 20 January 2021)

Morgenthaler, Hans R.: Architectural Volition, or What Does Form Mean? In: The Ethical Imperative: 106th Annual Meeting, Paper Proceedings. Eds.: Ameri, Amir H. - O’Neal Dagg, Rebecca. ACSA Press, Denver 2018. 328-334. 
Nasar, Jack L.: Perception and Evaluation of Residential Street Scenes. In: Environmental Aesthetics: Theory, Research, and Application. Ed.: Nasar, Jack L. Cambridge University Press, Cambridge 1988. 275-289.

Navez-Bouchanine, Françoise: Designers' Logic and Dwellers' Competence: Introduction. Architecture \& Comportement / Architecture \& Behaviour 10 (1995) 3. 242-246.

Oostendorp, Anke - Berlyne, Daniel E.: Dimensions in the Perception of Architecture - I. Identification and Interpretation of Dimensions of Similarity. Scandinavian Journal of Psychology 19 (1978) $73-82$.

Osgood, Charles E. - Suci, George J. - Tannenbaum, Percy H.: The Measurement of Meaning. University of Illinois Press, Urbana 1957.

Pennartz, Paul J. J. - Elsinga, Marja G.: Adults, Adolescents, and Architects - Differences in Perception of the Urban Environment. Environment and Behavior 22 (1990) 5. 675-714.

Pléh, Csaba - Czigler, István: Kísérlet politikai kifejezések megítélésére alkalmas szemantikus differenciálskálák kialakítására és alkalmazására. [An Attempt to Construct and Apply Semantic Differential Scales to Judge Political Expressions] In: Pszichológiai Tanulmányok XV. Szerk.: Hunyady György. Akadémiai, Budapest 1979. 479-533.

Proshansky, Harold M.: The City and Self-Identity. Environment and Behavior 10 (1978) 147-169.

Proshansky, Harold M. - Ittelson, William H. - Rivlin, Leanne G.: Freedom of Choice and Behavior in a Physical Setting. In: Environmental Psychology: Man and his Physical Setting. Eds.: Proshansky, H. M. - Ittelson, W. H. - Rivlin, L. G. Holt, Rinehart, and Winston, New York 1970. 173-183.

Relph, Edward: Place and Placelessness. Pion, London 1976.

Rosengren, Karl Erik: Communication. Sage Publications, London 2000.

Salama, Ashraf M. - Courtney, Leanne: The Impact of the Spatial Qualities of the Workplace on Architects' Job Satisfaction. International Journal of Architectural Research 7 (2013) 1. 52-64.

Schwarzer, Mitchell W.: The Emergence of Architectural Space: August Schmarsow's Theory of "Raumgestaltung." Assemblage 15 (1991) 48-61.

Sedgwick, Harold A.: Relating Direct and Indirect Perception of Spatial Layout. In: Looking into Pictures: An Interdisciplinary Approach to Pictorial Space. Eds.: Hecht, H. - Schwartz, R. Atherton, M. MIT Press, Cambridge 2003. 61-75.

Simon, Mariann: Az építészeti formáról. Hajnóczi Gyula két írása a hatvanas évek tükrében. [About Architectural Form. Gyula Hajnóczi's Two Writings in Reflection of the Sixties] ÉpitésÉpitészettudomány 26 (1997) 3-4. 279-288.

Soja, Edward W.: Postmodern Geographies: The Reassertion of Space in Critical Social Theory. Verso, London 1989.

Somogyi, Krisztina: Másképpen közelítve. Képalkotás a kortárs építészetről. [Approached Otherwise. Imaging Contemporary Architecture] In: Rábeszélötér. A szuggesztív kommunikáció környezetpszichológiája. Eds.: Dúll, Andrea - Varga, Katalin. L’Harmattan, Budapest 2015. 403-418.

Somogyi, Krisztina: Közvetlen élmény - közvetlen épitészet: az „épitész nézet” kvalitativ vizsgálata saját élményü középiskolai környezetben. [Direct Experience - Direct Architecture: A Qualitative Study of the "Architect's View" in a Self-Experienced High School Environment] PhD dissertation (supervisor: Dúll, Andrea - Cságoly, Ferenc) ELTE PPK Pszichológiai Doktori Iskola, Budapest 2019.

Steg, Linda - van den Berg, Agnes E. - de Groot, Judith I. M. (eds.): Environmental Psychology. An Introduction. BPS Blackwell, Malden 2013.

Sternberg, Robert J. - Sternberg, Karin: Cognitive Psychology. Cengage, Boston 2015.

Stokols, Daniel: Environmental Psychology. Annual Review of Psychology 29 (1978) 253-295.

Stokols, Daniel - Shumaker, Sally A.: People in Places: A Transactional View of Settings. In: Cognition, Social Behavior, and the Environment. Ed.: Harvey, J. H. Lawrence Erlbaum, Hillsdale 1981. 441-489.

Szabó, János: Hajnóczi Gyula (1920-1996). Épités- Épitészettudomány 26 (1997) 3-4. 199-205.

Vielhauer, Joyce Ardell: The Development of a Semantic Scale for the Description of the Physical Environment. Louisiana State University Historical Dissertations and Theses 1103. 1965. 
Wagemans, Johan et al.: A Century of Gestalt Psychology in Visual Perception: I. Perceptual Grouping and Figure-Ground Organization. Psychological Bulletin 138 (2012) 6. 1172-1217.

Wells, Jeremy C.: The Affect of Old Places: Exploring the Dimensions of Place Attachment and Senescent Environments. In: Place Meaning and Attachment: Authenticity, Heritage and Preservation. Eds.: Kopec, Dak - Bliss, Anna Marie. Routledge, New York 2020. 1-15.

\title{
HOGYAN ÉSZLELI KÖRNYEZETÉT A HOMO AEDIFICATOR?
}

\author{
A MÜEMLÉKEK PSZICHOLÓGIAI JELENTÉSÉNEK FELTÁRÁSA FELÉ
}

\author{
Összefoglaló
}

Miközben a magyarországi mủemlékvédelem jelenlegi válságának számos oka lehet, érdemes figyelmet fordítanunk arra, hogy mit tehetünk azért, hogy megerősítsük a közös értékek talaját; azt az alapot, amire olyan értelmes párbeszédeket építhetünk, melyek a történeti környezet értékelése és törődése iránti hajlandósághoz vezetnek. Egyre gyakrabban üti fel a fejét az a rejtett ellentét, ami a mủemlékes szakértők és a laikusok értékei között feszül. Szakértőként, átfogó ismerettel a történeti és építészeti értékekről, melyeket megtanultunk könnyen azonosítani, hasznos lehet a figyelmünket az emberekre, az ö jelentésadásaikra és értékeikre fordítanunk. Sokat okulhatunk a korábbi, emberközpontú építészetelméleti és gyakorlati példákból, melyek közül néhányat tanulmányunkban áttekintünk, kiemelve Hajnóczi Gyula munkásságát. Térelméletére és térészlelési gondolataira hivatkozva, különösen hálásak vagyunk a homo aedificator fogalmáért, utalva arra, hogy az építészet minden emberi lény anyagi és szellemi igényeit kielégíti. Felismerve az építész-nemépítész és ehhez hasonlóan a mủemlékes szakember-laikus közötti különbözőségek kihívásait, a környezetpszichológia segíthet az univerzális értékek felé vezető út megtalálásában. A szemantikus differenciál módszerét hívjuk segítségül az épített történeti környezet érzelmi jelentésének feltárására. Empirikus kutatásunk első lépéseivel betekintést nyerünk a mủemlékes szakemberek vélekedéseibe, pontosabban abba, hogy hogyan minősítik szakértelmük tárgyát. Bár már ezek az elözetes eredmények is - melyek rávilágítanak arra, hogy a szakemberek hogyan értelmezik a múemlékeket - érdekesek lehetnek, kutatásunk azzal a céllal folytatódik, hogy általánosságban feltárjuk az emberek vélekedéseit és a történeti épületeknek tulajdonított jelentéseket. Eredményeinkkel használható eszközöket kívánunk nyújtani a szakmabeliek és a laikusok közötti ellentétek feloldására.

Kulcsszavak: környezetpszichológia, épített örökség, történeti környezet, térészlelés, pszichológiai jelentés, szemantikus differenciál skála

Open Access statement. This is an open-access article distributed under the terms of the Creative Commons Attribution 4.0 International License (https://creativecommons.org/licenses/by/4.0/), which permits unrestricted use, distribution, and reproduction in any medium, provided the original author and source are credited, a link to the CC License is provided, and changes - if any - are indicated. (SID_1)

Received: 31 January 2021. Accepted: 4 February 2021

First published online: 22 February 2021 